\title{
A new species of Hennigmyia Peris, 1967 (Diptera: Muscidae) from the Oriental region
}

\author{
Новый виА Hennigmyia Peris, 1967 (Diptera: Muscidae) \\ из Ориентальной области
}

\author{
A.C. Pont ${ }^{1} \&$ N.E. Vikhrev ${ }^{2,3}$ \\ А.Ч. Понт ${ }^{1}$, H.E. Buxpeв ${ }^{2,3}$ \\ ${ }^{1}$ Oxford University Museum of Natural History, Parks Road, Oxford OX1 3PW, UK, and The Natural History Museum, Cromwell Road, \\ London SW7 5BD, UK. E-mail: pont.muscidae@btinternet.com \\ ${ }^{2}$ Zoological Museum, Lomonosov Moscow State University, Bolshaya Nikitskaya 6, Moscow, 125009 Russia. E-mail: nikita6510@ya.ru \\ Зоологический музей, Московский государственный университет им. М.В. Ломоносова, Большая Никитская 6, Москва 125009, Россия. \\ ${ }^{3}$ Corresponding author
}

KEY WORDS: Diptera, Muscidae, Hennigmyia, new species, Oriental region, elephant dung

КЛЮЧЕВЫЕ СЛОВА: Diptera, Muscidae, Hennigmyia, новый вид, Ориентальный регион, экскременты слонов

ABSTRACT. The genus Hennigmyia Peris, 1967 is known from three described Afrotropical species. We here describe a new species, Hennigmyia asiatica sp. n., from Thailand. Ecologically, H. asiatica seems closely connected with elephant dung.

РЕЗЮМЕ. Род Неnnigmyia Peris, 1967 известен по трем афротропическим видам. В данной работе описан новый вид, Hennigmyia asiatica sp.n., по материалу из Таиланда. Образ жизни $H$. asiatica, вероятно, тесно связан с экскрементами слонов.

\section{Introduction}

The genus Hennigmyia Peris, 1967 is a small genus currently known only from the Afrotropical region. It was originally described as Graueria by Curran [1935: 27] for the species Phaonia setinervis Stein, 1913 from Tanzania, but Graueria Curran is a junior homonym of Graueria Hartert, 1908 (Aves) and the replacement name Hennigmyia was proposed [Peris, 1967: 24]. Peris (op. cit.) also described a new species, H. ortizi, from Fernando Poo Island, whilst Zielke [1971: 73] added a third species, Hennigmyia zumpti, from South Africa. In the Natural History Museum, London, there are further apparently undescribed species from South Africa, Kenya, and Cameroon.

Hennigmyia (as Graueria) was included in his "Dichaetomyia group" of genera by Emden [1942: 676], but later Emden [1951: 377, 660] transferred the genus from his Dichaetomyiini to his Phaoniini. The genus was then discussed by Hennig [1965: 33], who examined a pair of Graueria setinervis and assigned the genus to the Muscini. He was followed by Peris [1967:
25], who quoted information sent to him by Hennig in 1964, and by Pont [1980: 723]. Finally, the genus has been defined and its position in the tribe Muscini confirmed, and it has been included in a key to world genera of the Muscini by Nihei \& Carvalho [2007, 2009].

We here describe a fourth species of Hennigmyia, the first to be found in the Oriental region. Taxonomically it is very close to the Afrotropical $H$. setinervis, but differs sufficiently in general habitus and colour characters to be treated as a distinct species. It has not previously been collected in Thailand or elsewhere in the Oriental region (S. Shinonaga, pers. comm.), and this may be due to its apparent close association with elephant dung.

Hennigmyia can be distinguished from other Oriental genera of the Muscidae by having the lower calypter of the Phaonia-type, anepimeron setulose, vein $\mathrm{R}_{1}$ setulose on dorsal surface, and sternite 1 bare. In Emden's [1965] key to genera, it will run to Polietes Rondani, from which it differs by the setulose vein $R_{1}$ and the bare prosternum. We have noted two modifications to the excellent diagnosis of this genus given by Nihei \& Carvalho [2009: 12]:

(1) The number of postsutural acrostichal setae is usually 3 pairs - always 3 in the new species, and 3 or 4 pairs in the African $H$. setinervis.

(2) We have studied five specimens of $H$. setinervis in the Natural History Museum, London, and in all but one female the stem-vein is bare, as in the Oriental species. One female has 1-2 very short dark setulae at the extreme tip of the stem-vein, and we believe these to be the first setulae of the row on vein $\mathrm{R}_{1}$ that have been slightly displaced, rather than true stem-vein setulae which are, generally, longer and finer than the setulae present in this female. 


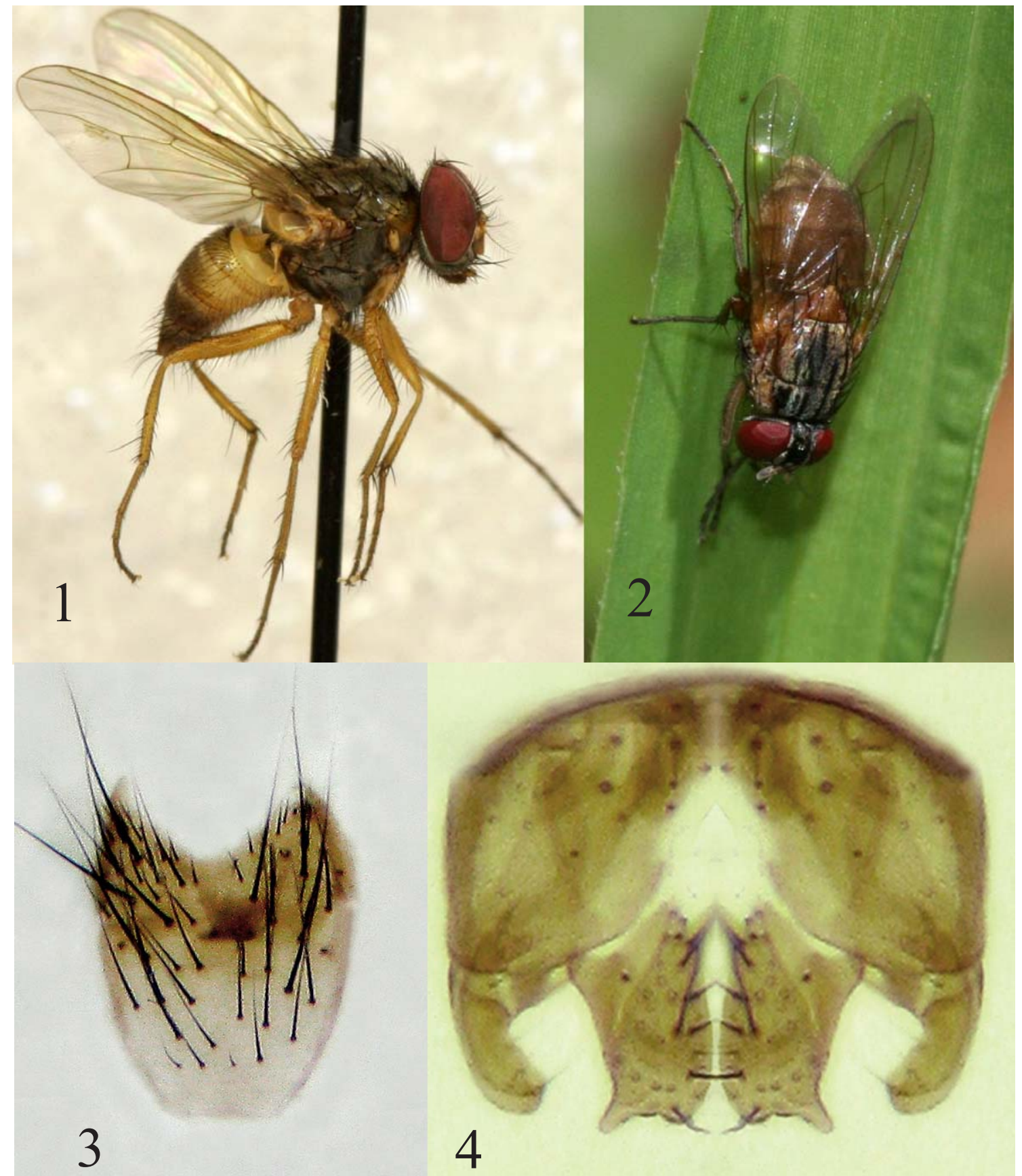

Figs 1-4. Hennigmyia asiatica, sp.n.: 1 - male, holotype; 2 - female; 3 - male sternite $5 ; 4$ - cercal plate and surstyli, dorsal view. Рис. 1-4. Hennigmyia asiatica, sp.n.: 1 - голотип, самец; 2 - самка; 3 - 5-й стернит самца; 4 - церки и сурстили.

\section{Hennigmyia asiatica sp.n.}

Figs 1-4.

MATERIAL. Holotype $\bigcirc^{7}$, THAILAND, Phang Nga province, Khao Lak env., elephant camp, $8.760^{\circ} \mathrm{N} 98.284^{\circ} \mathrm{E}, 16-21 . \mathrm{XII} .2009$, N.Vikhrev.

Paratypes: THAILAND, Phang Nga province, Khao Lak env., elephant camp: $8.616^{\circ} \mathrm{N} 98.245^{\circ} \mathrm{E}, 14-17 . X I I .2009$, N.Vikhrev, $50^{7} \mathrm{O}^{7} 17$ 우 $; 8.712^{\circ} \mathrm{N} 98.254^{\circ} \mathrm{E}, 16-24 . X I I .2009$, N.Vikhrev, $80^{7} \mathrm{O}^{\prime}$ 15 우우 elephant camp, $8.760^{\circ} \mathrm{N} 98.284^{\circ} \mathrm{E}, 16-21 . X I I .2009$ N.Vikhrev, $20^{7} \sigma^{7} 16+9$; 21.XII.2009, N.Vikhrev, $40^{7} 0^{7}$, 4우; Mae Hong Son prov., Pai env., elephant camp, $19.31^{\circ} \mathrm{N} 98.46^{\circ} \mathrm{E}, 15$ 20.XI.2010, N.Vikhrev, $10^{7}$.
The holotype and most paratypes are in the Zoological Museum of Moscow University. $4 \sigma^{7} O^{T}$ and 5 ㅇ paratypes are in the Natural History Museum, London.

DIAGNOSIS. Hennigmyia asiatica sp.n. can be distinguished from other species of the genus by dark colour of the thorax, the whitish-yellow calypters of the male, and the darkened postpedicel of the female.

DESCRIPTION. The following abbreviations for morphological structures are used: $f 1, t 1, f 2, t 2, f 3, t 3=$ fore-, mid-, hind- femur or tibia; $a c=$ acrostichal setae; 
$d c=$ dorsocentral setae; $a, p, d, v=$ anterior, posterior, dorsal, ventral seta(e), post $=$ postsutural.

Male (Fig. 1). Body length 5.0-5.5 mm.

Head holoptic; frons at narrowest point separated by less than diameter of anterior ocellus, the narrow frontoorbital plates touching in upper part of frons; eye almost bare, with short and sparse hairs. Upper inner eye facets enlarged as usual, but not strikingly so. Upper half of fronto-orbital plate matt, lower half and parafacial silvery pruinose, gena and lower occiput grey. 6-8 pairs of inclinate frontal setae, confined to lower half of frons, and just before occiput with 1 pair of weak proclinate and 1 pair of weak reclinate orbital setae. Parafacial narrow, hardly wider than diameter of anterior ocellus. Antenna yellow, inserted at mid level of eye, postpedicel partially infuscated in apical half Arista long plumose, aristal hairs twice as long as width of postpedicel. Beard partly golden. Palpus yellow to dull yellow, narrow and short. Proboscis short, mentum thinly dusted.

Thorax dark in ground-colour, postpronotal lobe yellow, scutellum yellowish, anterior spiracle yellow, posterior spiracle brownish. Scutum yellowish-grey dusted, with two pairs of black vittae: a narrow submedian vitta between $a c$ and $d c$ rows, reaching from neck almost to 2 nd post $d c$; a lateral vitta between $d c$ and intra-alar rows, broadly interrupted at suture. Scutellum with a patch of grey dust in each lateral basal corner. Prosternum narrow, broadened anteriorly, reddish-brown, bare. Setae: ac 3+3, post setulae in 6 rows; $d c 2+3$; notopleuron setulose; prealar seta slightly shorter than posterior notopleural; katepisternals $1+2$; anepimeron densely setulose on posterior half; subalar bulla bare; katepimeron with 1-3 setulae; meron with several hairs above hind coxa; katatergite without pile; anatergite bare. Posterior spiracle without setulae on lower and posterior margins. Suprasquamal ridge bare. Scutellum setulose laterally but bare ventrally.

Wing clear, slightly yellowish, evenly covered with microtrichia. Basicosta and tegula yellow. Subcostal sclerite and stem-vein bare. Vein $\mathrm{R}_{1}$ setulose dorsally along its whole length, ventrally with 1-2 setulae near apex. Vein $\mathrm{R}_{4+5}$ setulose dorsally and ventrally, setulae reaching cross-vein $\mathrm{r}-\mathrm{m}$. Vein $\mathrm{M}$ straight, not curved forward in apical section towards vein $R_{4+5}$. Calypters white to yellowish, the margin of the lower one deep yellow; lower calypter of the Phaonia-type, twice as long as upper one. Haltere yellow.

Legs entirely yellow except for the apical 1-2 tarsomeres. $f 1$ with the usual $p d$ and $p v$ rows of setae. $t 1$ without seta. $f 2$ in basal half with a row of shorter $a v$ and longer $p v$ setae, and with $0 a$ and $3 p d-p$ preapicals. t2 with 3-4 p-setae. Hind coxa bare on posterior margin. $f 3$ with complete rows of $a d$ and $a v$ setae, with 5 long and fine $p v$ in basal half; with $2 d$ and $1 p d$ preapicals. $t 3$ with 4 (3-5) av, 1 median $a d$ and 1 long $p d$ ("calcar") in apical third; with a $p d$ ctenidium of short stout setulae on apical two-fifths; $d$ and $a d$ preapicals present; $1 a v$ but $0 p v$ apical. Tarsus of fore leg with an erect curled hair at base, middle and tip of tarsomere 1 and at the tips of tarsomeres 2-4, other- wise tarsi unmodified. Pulvilli small.

Abdomen yellow without distinct pattern, subshining, with some grey dust confined to anterior lateral corners of tergite 5 . Tergites 4 and 5 each with a row of marginal setae, and tergite 5 with a discal row. Sternite 1 bare. Sternite 5 as in Fig. 3. Terminalia as in Fig. 4.

Female (Fig. 2). Differs from the male as follows:

Body length slightly greater, 5.5-6.0 mm. Head dichoptic, frons about one-third of head width. Frontoorbital plate entirely silvery pruinose. Parafacial with a matt patch opposite insertion of antenna. 4-6 pairs of inclinate frontal setae, a pair of strong proclinate and 2 pairs of short reclinate orbitals; 1 pair of crossed interfrontals present. Fronto-orbital plate bare outside the setae. Antenna darker, mainly brown, only clear yellow on basal quarter of postpedicel. Parafacial rather broader. Thorax with the yellow colour on scutum more developed, usually lateral part of scutum dirty-yellow and pleura partly yellowish. Scutum with the post vittae broader and after $2 \mathrm{nd} d c$ coalescing to form a single vitta on each side that reaches almost to scutellum. Calypters paler, entirely whitish-yellow. Legs with the $p v$ setae on $f 2$ and $f 3$ shorter, $f 2$ with an $a$ preapical.

ETYMOLOGY. The species epithet refers to the geographic occurrence of the new species on the continent of Asia, and is an adjective in agreement with the feminine noun Hennigmyia.

RELATIONSHIPS. H. asiatica sp.n. is most closely similar to the Afrotropical $H$. setinervis, and can be separated from it by the following key couplet:

- Scutum dark in ground-colour, only the postpronotal lobe yellow ( $\sigma^{7}$, Fig. 1) or postpronotal lobe and the area outside the supra-alar line yellow ( + , Fig. 2$)$. $O^{7}$ : upper inner eye facets enlarged as usual, but not strikingly so; calypters white to yellowish, with deep yellow margins. q: postpedicel dark brown in apical half or more. Thailand .................................................... H. asiatica sp.n.

- Thorax yellow, at most scutum partly darkened. $\sigma^{7}$ : upper inner eye facets strikingly enlarged and contrasting with the lower facets; calypters smoky white with brown margins. + : postpedicel wholly yellow. Tanzania, Uganda, Democratic Republic of the Congo

H. setinervis (Stein)

ECOLOGY. All specimens of $H$. asiatica sp. n. were collected on or around elephant dung near so-called "elephant camps" - the sites for elephant riding in what is allegedly jungle but which is usually among secondary vegetation such as abandoned Hevea plantations.

ACKNOWLEDGEMENTS. We thank Dr Satoshi Shinonaga (Tokyo, Japan) for information on Hennigmyia in the Oriental region.

\section{References}

Curran C.H. 1935. African Muscidae. - II // American Museum Novititates. No.776. P.1-27.

Emden F.I. van. 1942. Keys to the Muscidae of the Ethiopian Region: Dichaetomyia-group. [Part.] // Annals and Magazine of natural History. Ser.11. Vol.9. P.673-701. 
Emden F.I. van. 1951. Muscidae: C. - Scatophaginae, Anthomyiinae, Lispinae, Fanniinae and Phaoniinae // Ruwenzori Expedition 1934-35. British Museum (Natural History), London. Vol.2. No.6. P.325-710.

Emden F.I. van. 1965. The Fauna of India and the adjacent countries. Diptera, 7, Muscidae, part 1. Government of India. Delhi. xiv +647 pp., 156 figs, 2 plates.

Hennig W. 1965. Vorarbeiten zu einem phylogenetischen System der Muscidae (Diptera: Cyclorrhapha) // Stuttgarter Beiträge zur Naturkunde. Vol.141. $100 \mathrm{~S}$

Nihei S.S., Carvalho C.J.B. de. 2007. Phylogeny and classification of Muscini (Diptera, Muscidae) // Zoological Journal of the Linnean Society. Vol.149. No.4. P.493-532.
Nihei S.S., Carvalho C.J.B. de. 2009. The Muscini flies of the world (Diptera, Muscidae): identification key and generic diagnoses // Zootaxa. Vol.1976. P.1-24.

Peris S.V. 1967. Los Muscini de la Guinea Española. Claves para la identificación y notas sobre las especies etiópicas (Diptera, Muscidae) // Boletin de la Real Sociedad española de Historia natural (Seccion Biologica). Vol.65. No.1-2. P.21-64

Pont A.C. 1980. Family Muscidae // Crosskey R.W. (ed.). Catalogue of the Diptera of the Afrotropical Region. British Museum (Natural History). London. U.K. P.721-761.

Zielke E. 1971. Description of eight new Phaoniinae species from the Ethiopian region (Diptera, Muscidae) // Beiträge zur Entomologie. Vol.21. No.1-2. P.71-77. 